\title{
News in Celiac Disease about Differential Diagnosis from Romania
}

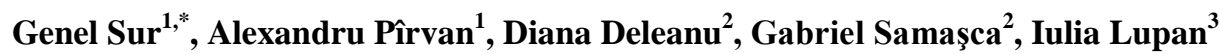 \\ ${ }^{1}$ Department of Pediatrics II, Iuliu Hatieganu University of Medicine and Pharmacy, Cluj-Napoca, Romania \\ ${ }^{2}$ Department of Immunology, Iuliu Hatieganu University of Medicine and Pharmacy, Cluj-Napoca, Romania \\ ${ }^{3}$ Department of Molecular Biology and Biotechnology, Babes-Bolyai University, Cluj-Napoca, Romania \\ *Corresponding author: surgenel@yahoo.com
}

Received March 29, 2014; Revised March 31, 2014; Accepted April 01, 2014

\begin{abstract}
Evolution of celiac disease is continuously changing. Celiac disease has become a public health problem in some countries. Knowledge of the disease evolution is important to find current problems of disease. In this article, we wanted to discuss the recent medical and diagnostic discoveries from Romania.
\end{abstract}

Keywords: evolution, medical considerations, diagnostic approach, gluten-free diet, Romania, European context

Cite This Article: Genel Sur, Alexandru Pîrvan, Diana Deleanu, Gabriel Samaşca, and Iulia Lupan, "News in Celiac Disease about Differential Diagnosis from Romania." International Journal of Celiac Disease, vol. 2, no. 2 (2014): 40-43. doi: 10.12691/ijcd-2-2-2.

\section{Introduction}

The first records of the study of celiac disease in Romania were reported in 1966 [1,2]. Different researcher assessed clinical and laboratory aspects and classification of malabsorption syndromes in the following years [3,4,5]. The collaborations with foreign researchers began in 1992 . The conclusion of the study group was that CD diagnosing varied from many standard texts in Great Britain [6]. In Romania, the professor Nicolae Miu was the pioneer in the CD study at that time. The value of jejunal biopsy was emphasized on diagnosis and monitoring of the treatment [7]. The ultrastructural changes have been noticed in the jejunal mucosa by scanning electron microscopy in CD children [8]. A special case of a patient with fatal hemorrhage from small intestinal lymphoma complicating unresponsive CD treated with cyclosporine was reported in 1997 [9]. Therefore jejunal biopsy was not enough for preventing long-term complications in CD. Although the gold standard for CD diagnosis was the small bowel biopsy, in early of 2000 the first serological tests began to be used for the diagnosis of CD. IgA anti-tissue transglutaminase antibodies (tTG) were 100\% positive in patients with clinical suspicion of CD, the diagnosis being confirmed by biopsy. Serum antiendomisium antibodies (EMA) levels correlated perfectly with histological alterations [10].

Recent years have brought constant changes in CD diagnosis. In 2010, the CD prevalence was 1\% in Europe population. Many associations with CD were found, e.g. autoimmune type 1 diabetes mellitus (T1DM), osteoporosis or Sjogren's syndrome [11]. Four types were defined according to the Oslo definition of CD: 1). Classical CD the patients present gastrointestinal signs and symptoms; 2). Non-classical CD - the patients do not present typical gastrointestinal manifestations; 3). Subclinical CD - the patients present autoimmune and genetic conditions or first degree relatives to patients; 4). Potential CD - the patients present positive serology, but minimally abnormal changes in intestinal biopsies [12]. Identification of large number of $\mathrm{CD}$ associations has led to the increasing prevalence of CD in recent years [13]. The introduction of serological tests as a screening test of CD has also contributed to increasing prevalence of CD from recent years [14]. DQ2 prevalence was 5-20\% in Western Europe but DQ8 prevalence was $<5 \%$ in Eastern Europe [15]. Laboratory tests had a great explosion, e.g. tTG, EMA and antibodies against synthetic deamidated gliadin peptides (DGP). Gluten toxicity screening has been extensively studied [16]. The persistence of more than 6-12 months of symptoms of malnutrition and intestinal villous atrophy although the patient follows a strict gluten-free diet (GFD) was called refractary celiac disease (RFC). RFC has become a challenge in immunology [17].

The aim of our review was to follow the evolution of $\mathrm{CD}$ diagnosis in the last years from Romania in European context. We studied all articles about CD written by Romanian researchers or foreign researchers about Romania.

\section{Results and Discussions}

Intraepithelial lymphocytes were helpful in early recognising of $\mathrm{CD}$ but the finding was not specific. Therefore the histopathology exam of duodenal biopsy remained the gold standard of the diagnosis of CD in the years 2009-2010 [18,19]. Capsule endoscopy technology was proposed due to image quality provided with the intestinal villi [20]. Ciobanu et al. proposed capsule endoscopy for the diagnosis of $\mathrm{CD}$ in patients with Crohn's disease not responding to immunosuppressant or biological treatment [21]. 


\subsection{Medical Considerations}

The prevalence of $\mathrm{CD}$ in the pediatric population has been increasing in recent years: 4.09\% [22], 8.7\% [23] and $11.2 \%$ [24]. The prevalence of CD in adult population was found to be $2.22 \%$ [25], but this study is old and a new study unfortunately does not exist. Therefore a comparison between the CD prevalence in children and adults is not possible. However, the highest prevalence according to Marsh classification has it the form Marsh IIIc (46\%) among adult patients with CD [26,27]. T1DM and the first degree relatives of $\mathrm{CD}$ patients have been identified as high risk groups. Association of CD with T1DM has been the subject of many studies [28]. The CD prevalence among the T1DM patients in Romania was $3.9 \%$ that is comparable with European studies in adult patient with CD [29]. The IgA anti-tTG prevalence in children with T1DM was 9.2\%, and sensitivity and specificity of IgA anti-tTG were 80 and $82.6 \%$ [30]. Another association of CD is with Turner syndrome, in which besides GFD, the patient requires endocrine treatment [31]. Ioniță-Radu et al. presented a case of young women, who developed CD during the treatment for chronic hepatitis $C$. What could be the cause? The study authors concluded that interferon and ribavirin therapy are associated with induction or exacerbation of preexistent autoimmune disorders [32]. Samasca et al. proposed $\mathrm{CD}$ screening in hepatitis $\mathrm{C}$, respectively determination of IgA anti-tTG before and after starting treatment with interferon [33]. Altered liver function was also found in 12 from 120 CD diagnosed patients [34].

\subsection{Diagnosis Approach}

A combination of most specificity and sensitivity IgA anti-EMA and IgA anti-tTG was used as screening tests for risk populations such as T1DM, Turner syndrome, William's syndrome, immunoglobulin A deficiency and first degree relatives of CD patients [35]. Samasca et al. proposed IgA anti-tTG as a screening methods [36], as did their predecessors [37]. Possible association between asymptomatic $\mathrm{CD}$ and dermatitis herpetiformis was revealed [38]. New tests (IgG-F-actin antibodies) have been evaluated in CD and dermatitis herpetiformis but the results were not relevant [39]. IgA+IgG DGP were evaluated as a new serological test. Conclusion was that IgA+IgG DGP is a useful test as serological marker for the $\mathrm{CD}$ screening and at the same time in the immunoglobulin A deficit for the 0-3 years age group. IgA+IgG DGP was also a test of high precision diagnostic value in all child age groups [40]. Recently, Belei and Marginean have proposed a new test, a combination of DGP and tTG, namely IgA/IgG DGP/tTG screen assay for $\mathrm{CD}$ detection among symptomatic and at risk young children [41]. Genetic tests have been introduced to the diagnosis and prognosis of CD. The study authors have emphasized the genetic testing importance in relatives of patients with $\mathrm{CD}$, where serological tests were negative but genetic tests were positive [42,43].

A question was whether serological tests can replace duodenal biopsy? Duodenal biopsy during the routine gastrointestinal endoscopy has recommended being included in clinical practice as a diagnostic method of CD in high risk symptomatic patients and those with anemia and / or chronic diarrhea [44]. Samasca et al. presented a case report that brings a question about a rapid and certain diagnosis in CD with secondary lactose intolerance, given by serological tests compare with duodenal biopsy, a more invasive, children unpleasant [45]. The same opinion is shared by Nur Arslan, related to the performance of IgA/IgG DGP/tTG in young children compared with duodenal biopsy [46]. Popp et al. concluded that high IgA anti-tTG titres do not require endoscopy with duodenal biopsies for CD diagnosis in children with T1DM. But the patients with lower IgA anti-tTG positive antibodies need duodenal biopsy [47]. These conclusions are in line with the recommendations of the European Society for Paediatric Gastroenterology, Hepatology, and Nutrition (ESPGHAN) [48]. A rare manifestation of CD was described, namely: the cavitating mesenteric lymph node syndrome with an estimated mortality rate of 50\% [49]. Mosteanu et al. proposed spiral enteroscopy for patients who are developing complications during CD follow-up [50].

\subsection{Gluten-free Diet}

GFD is difficult to follow. Improving quality of life (QOL) of patients with CD that follows a GFD has been an important concern in Europe [51]. Anca et al. established that supported groups, better prices and food labeling would improve the QOL of CD patients [52]. But Samasca et al. concluded that GFD should be understood first by the families of children with CD [53]. Unfortunately, we have same circumstances among Romanian immigrants in northern Italy. The twin nostalgia of immigrant children for foods and tastes from the native country represents a problem that will be difficult to resolve [54]. A balanced caloric GFD, fat and protein to make sure an ideal nutritional status and prevent long-term complications is also necessary [55]. The genetic variability of wheat [56], the use of microbial biotechnology [57], bake-off technology [58] can also provide solutions to gluten-free products of CD patients. The immunochromatographic assay was an efficient rapid tool for gluten toxicity screenings, as an alternative to the enzyme-linked immunosorbent assay (ELISA) techniques [59]. This is an important issue for detection of gluten in dietary supplements that is highly important to the safety of products consumed by $\mathrm{CD}$ and gluten-sensitive patients [60]. Therefore, a special attention should be given to gluten screening toxicity.

\section{Conclusions}

Following the diagnosis of $\mathrm{CD}$ in the last years, we established the following: 1). New diagnostic methods (serological tests, capsule endoscopy technology) but with persistent of duodenal biopsy as gold standard have characterised the years 2008-2010; 2). Studies were focused on the CD association from 2010. Serologic tests have identified CD as being associated with many other autoimmune diseases, like T1DM, osteoporosis, Sjogren's syndrome, Turner syndrome, William's syndrome, immunoglobulin A deficiency. The serological importance increased compared with duodenal biopsy in the last years. Genetic testing is also important to relatives of CD patients as a risk factor. 


\section{References}

[1] Surianu, P., Dumitraşcu, D., Munteanu, P., "Gluten enteropathy (clinical and therapeutic considerations)," Med Interna (Bucur), 18(7), 843-848, Jul 1966.

[2] Rusescu, A., Veidenfeld, R., "Current aspects of etiopathogenesis and therapy of celiac disease and some implications of those aspects in current problems of infantile medicine," Pediatria (Bucur), 15(5), 435-440, Sep-Oct 1966.

[3] Gheorghescu, B., Oproiu, A., Vasilescu, F., Aposteanu, G., Jovin, G., Rucăreanu, I., "Gluten enteropathy. Clinical and nosological considerations," Med Interna (Bucur), 23(10), 1197-1207, Oct 1971.

[4] Pap, Z., Metz, O., Puskás, E., "Enzyme deficiencies and malabsorption syndromes following non-specific chronic enteropathies and celiac disease in children,” Pediatria (Bucur), 21(4), 323-326, Jul-Aug 1972.

[5] Iancu, A.T., Iancu, A.V., "Current trend to reconsideration of the classification of malabsorption syndromes. Enteropathy caused by gluten," Rev Med Chir Soc Med Nat Iasi, 78(2), 283-287, Apr 1974.

[6] Acalovschi, M., Jayanthi, V., Probert, C.S., Mayberry, J.F., "Management of coeliac disease: a changing diagnostic approach but what value in follow up?," Qual Health Care, 1(1), 26-28, Mar 1992.

[7] Miu, N., Lakatos, S., Slăvescu, L., Florescu, P., Baciu, C., "The celiac syndrome. The clinico-histological correlations," Pediatrie (Bucur), 41(2), 57-65, Apr-Jun 1992.

[8] Miu, N., Diculescu, C.D., Porr, P.J., Lakatos, S., Florescu, P., Chicinas, I., "The ultrastructural changes in the jejunal mucosa in gluten-sensitive enteropathy in children demonstrated by scanning electron microscopy,” Pediatrie (Bucur), 40(1-2), 125-129, 1991.

[9] Gheorghe, L., Popescu, I., Gheorghe, C., Aposteanu, G., Popescu, C., Oproiu, A., "Fatal intestinal hemorrhage complicating ileal lymphoma after cyclosporine for unresponsive celiac disease," Hepatogastroenterology, 44(17), 1342-1345, Sep-Oct 1997.

[10] Tărmure, S., Grigorescu, M., Cristea, A., Togănel, E., Dumitra, D., "Antiendomysial and antitissue transglutaminase antibodies in gluten-induced enteropathy.," Rom J Gastroenterol, 11(2), 91-95, Jun 2002.

[11] Ioniță-Radu, F., Pătrăşescu, M., "Celiac disease--a continuous challenge," Rom J Intern Med, 48(3), 233-237, Jul-Sep 2010.

[12] Ludvigsson, J.F., Leffler, D.A., Bai, J.C., Biagi, F., Fasano, A., Green, P.H., Hadjivassiliou, M., Kaukinen, K., Kelly, C.P., Leonard, J.N., Lundin, K.E., Murray, J.A., Sanders, D.S., Walker, M.M., Zingone, F., Ciacci, C., "The Oslo definitions for coeliac disease and related terms," Gut, 62(1), 43-52, Jan 2013.

[13] Nevoral, J., "Celiac Disease in Children: What Has Changed?," International Journal of Celiac Disease, 2(1), 18-23, 2014.

[14] Rimarova, K., "Celiac Diseases - Global Demographic Context and Slovakia," International Journal of Celiac Disease, 1(1), 1718, 2013.

[15] Kang, J.Y., Kang, A.H., Green, A., Gwee, K.A., Ho, K.Y., "Systematic review: worldwide variation in the frequency of coeliac disease and changes over time," Aliment Pharmacol Ther, 38(3), 226-245, Aug 2013.

[16] Samaşca, G., Sur, G., Lupan, I., "Current trends and investigative developments in celiac disease," Immunol Invest, 42(4), 273-284, May 2013.

[17] Samasca, G., Lupan, I., Deleanu, D., Cristea, V., Makovicky, P., "Immunological Approach of the Challenges of the XXI Century in Celiac Disease,” Int Rev Immunol, 33(1), 3-8, Jan 2014.

[18] Ghimpu, S., Bozomitu, L., Cârdei, E., Oltean, C., Burlacu, M., Anton, D., Trandafir, L., Mihăilă, D., Moraru, D., "Helicobacter pylori infection in children with celiac disease," Rev Med Chir Soc Med Nat Iasi, 113(4), 1093-1098, Oct-Dec 2009.

[19] Ghimpu, S., Bozomitu, L., Cîrdei, E., Mihlăilă, D., Boldureanu, D., Moraru, D., "Evidence of intraepithelial lymphocytes through immunocytochemistry stains in children with celiac disease," Rev Med Chir Soc Med Nat Iasi, 114(1), 170-174, Jan-Mar 2010.

[20] Vere, C.C., Rogoveanu, I., Streba, C.T., Popescu, A., Ciocalteu, A., Ciurea, T., "The role of capsule endoscopy in the detection of small bowel disease," Chirurgia (Bucur), 107(3), 352-360, May 2012.

[21] Ciobanu, L., Pascu, O., Iobagiu, S., Damian, D., Dumitru, E., Tantau, M., "Unknown complicated celiac disease as an unexpected finding in patients investigated with capsule endoscopy for Crohn's disease. A case series,” J Gastrointestin Liver Dis, 22(1), 97-100, Mar 2013.

[22] Belei, O., Simedrea, I., Marazan, M., Marcovici, T., Daescu, C., Ilie, R., Antonie, F., Brad, G., "Correlation of villous alterations in celiac disease pediatric patients with risk factors analyse," The Pediatric's Journal (Rom), 12(47-48), 40-44, Jul-Dec 2009.

[23] Popp, A., Jinga, M., Jurcut, C., Balaban, V., Bardas, C., Laurila, K., Vasilescu, F., Ene, A., Anca, I., Mäki, M., "Fingertip rapid point-of-care test in adult case-finding in coeliac disease," BMC Gastroenterology, 13(1), 115, Jul 2013.

[24] Sur, G., Floca, E., Sur, L., Sur, D., Samasca, G., “Clinical presentation of celiac disease; Masks therapeutic perspectives of celiac disease," Pharmaceutica Analytica Acta, 4(4), 1000228, Apr 2013.

[25] Dobru, D., Pascu, O., Tanță, M., Gheorghe, C., Goldiş, A., Bălan, G., Olteanu, I., Fraticiu, A., Dumitru, E., Miuțescu, E., Mulder, C., Podoleanu, S., "The prevalence of coeliac disease at endoscopy units in Romania: routine biopsies during gastroscopy are mandatory (a multicentre study)," Rom J Gastroenterol, 12(2), 97100, Jun 2003.

[26] Ehsani-Ardakani, M.J., Rostami Nejad, M., Villanacci, V., Volta, U., Manenti, S., Caio, G., Giovenali, P., Becheanu, G., Diculescu, M., Pellegrino, S., Magazzù, G., Casella, G., Di Bella, C., Decarli, N., Biancalani, M., Bassotti, G., Hogg-Kollars, S., Zali, M.R., Rostami, K., "Gastrointestinal and Non-gastrointestinal Presentation in Patients with Celiac Disease," Arch Iran Med, 16(2), 78-82, Feb 2013.

[27] Rostami-Nejad, M., Villanacci, V., Hogg-Kollars, S., Volta5, U., Manenti3, S., Reza-Zali1, M., Caio5, G., Giovenali, P., Barakauskiene, A., Kazenaite, E., Becheanu, G., Diculescu, M., Pellegrino, S., Magazzù, G., Casella, G., Di-Bella, C., Decarli, N., Biancalani, M., Bassotti, G., Rostami, K., "Endoscopic and histological pitfalls in the diagnosis of celiac disease: A multicentre study assessing the current practice,” Rev Esp Enferm Dig (Madrid), 105(6), 326-333, 2013.

[28] Cev, E.Z., Pascu, O., "Celiac disease and type 1 diabetes mellitus epidemilogical, clinical and therapeutical particularities," Medicina modernă, 16, 622-626, 2009.

[29] Cev, E.Z., Pascu, O., Serban, V., Mulder, C.J.J., Taban, S., Samasca, G., "The Prevalence of Celiac Disease in Adult and Adolescent Romanian Patients With Type 1 Diabetes Mellitus," TMJ, 60(2-3), 189-195, Apr-Sep 2010.

[30] Gabriel, S., Mihaela, I., Angela, B., Mariana, A., Doru, D., "Prevalence of IgA antitissue transglutaminase antibodies in children with type 1 diabetes mellitus," J Clin Lab Anal, 25(3), 156-161, May-Jun 2011.

[31] Popp, A.S., Anca, I.A., Bica, V., Ionesti, C., Alexe, G., "Association of celiac disease and turner syndrome," Acta Endocrinologica (Buc), 3(1), 93-99, Jan-Mar 2007.

[32] Ioniță-Radu, F., Bucurică, S., Costache, R., Nuță, P., Stanciu, S., "An adult case with onset of celiac disease during chronic hepatitis C antiviral treatment," Rom J Intern Med, 48(1), 105-108, Jan-Mar 2010.

[33] Samaşca, G., Burac, L., Farcău, D., Dejica, D., „Celiac disease screening in chronic viral hepatitis C,” Ro J Pediatr, 59(1), 49-50, Jan-Mar 2010.

[34] Ozkan, M., Trandafir, L., Bozomitu, L., Azocai, A., Murgu, A., Popovici, P., Stana, B., Tunza-Enea, H.A., Moraru, E., "Liver involvement in celiac disease in children,” Rev Med Chir Soc Med Nat Iasi, 115(4), 1030-1034, Oct-Dec 2011.

[35] Belei, O., Simedrea, I., Marazan, M., Ilie, R., Daescu, C., Marcovici, T., "Accuracy of Serological Tests in Celiac Disease Children,” TMJ, 59(3-4), 290-296, Jul-Dec 2009.

[36] Samaşca, G., Iancu, M., Farcău, D., Butnariu, A., Pop, T., Pîrvan, A., Andreica, M., Miu, N., Cristea, V., Dejica, D., "IgA anti-tissue transglutaminase antibodies, first line in the diagnosis of celiac disease," Clin Lab, 57(9-10), 695-701, Sep-Oct 2011.

[37] Tărmure, S., Cristea, A., Sămpelean, D., Negrean, V., Alexescu, T., "Serological and histological correlations in celiac disease," Rom J Intern Med, 45(3), 263-268, 2007.

[38] Samaşca, G., Băican, A., Pîrvan, A., Dejica, D., "Dermatitis Herpetiformis,” Romanian Journal of Medical Laboratory, 4 (15), 23-27, 2009.

[39] Samaşca, G., Băican, A., Pop, T., Pîrvan, A., Miu, N., Andreica, M., Cristea, V., Dejica, D., "IgG-F-actin antibodies in celiac disease and dermatitis herpetiformis," Roum Arch Microbiol Immunol, 69(4), 177-182, Oct-Dec 2010. 
[40] Samaşca, G., Iancu, M., Butnariu, A., Andreica, M., Dejica, D., "New Para-Clinical Investigations in the Celiac Disease," Rev Romana Med Lab, 18(2), 43-51, Jun 2010.

[41] Belei, O., Marginean, O., "The Usefulness of IgA/IgG DGP/tTG Screen Assay for Celiac Disease Detection among Symptomatic and at Risk Young Children," International Journal of Celiac Disease, 1(1), 23-26, 2013.

[42] Samaşca, G., Iancu, M., Butnariu, A., Andreica, M., Constantinescu, I., Dejica, D., „The importance of determining human leucocyte antigens in preventing intestinal lymphoma in patients with celiac disease," Anal. Şt. Ale Univ. Al.I. Cuza” Iaşi, Secțiunea II a.Genetică şi Biologie Moleculară, 11(2-3), 81-87, Apr-Sep 2010.

[43] Samaşca, G., Iancu, M., Pîrvan, A., Andreica, M., Miu, N., Constantinescu, I., Cristea, V., Dejica, D., "Histocompatibility risk antigens in celiac disease in children," Clujul Medical Journal, 84(2), 269-273, Apr-Jun 2011.

[44] Cev, E.Z., Pascu, O., Taban, S., "Importance of duodenal biopsy during routine upper gastrointestinal endoscopy for diagnosis of celiac disease,” Journal of Experimental Medical \& Surgical Research, 17(1), 23-27, Jan-Mar 2010.

[45] Samasca, G., Bruchental, M., Butnariu, A., Pirvan, A., Andreica, M., Cristea, V., Dejica, D., "Difficulties in Celiac Disease Diagnosis in Children - A case report,” Maedica (Buchar), 6(1), 32-35, Jan 2011.

[46] Nur, A., "Towards Finding More Diagnostic Serological Markers in Celiac Disease: Can Deamidated Gliadin Peptide Antibodies Help to Our Babies?” International Journal of Celiac Disease, 1(1), 27-28, 2013.

[47] Popp, A., Mihu, M., Munteanu, M., Ene, A., Dutescu, M., Colcer, F., Raducanu, D., Laurila, K., Anca, I., Mäki, M., "Prospective antibody case finding of coeliac disease in type-1 diabetes children: need of biopsy revisited," Acta Paediatr, 102(3), e102-106. Mar 2013.

[48] Kurppa, K., Salminiemi, J., Ukkola, A., Saavalainen, P., Löytynoja, K., Laurila, K., Collin, P., Mäki, M., Kaukinen, K., "Utility of the new ESPGHAN criteria for the diagnosis of celiac disease in at-risk groups,” J Pediatr Gastroenterol Nutr, 54(3), 387-391, Mar 2012.

[49] Pojoga, C., Ciobanu, L., Badea, A.F., Boțan, E., Caraiani, C., Hagiu, C., Băciuț, G., Badea, R., "2D ultrasonography and contrast enhanced ultrasound for the evaluation of cavitating mesenteric lymph node syndrome in a patient with refractory celiac disease and enteropathy $\mathrm{T}$ cell lymphoma," $B M C$ Gastroenterol, 13, 26, Feb 2013.

[50] Mosteanu, O., Pop, T.A., Hadade, A., Tanțău, M., „Spiral Enteroscopy Value for the Celiac Disease Diagnosis and Management," International Journal of Celiac Disease, 2(1), 2730, 2014.

[51] Troncone, R., Ivarsson, A., Szajewska, H., Mearin, M.L., Members of European Multistakeholder Platform on CD (CDEUSSA)., "Review article: future research on coeliac disease a position report from the European multistakeholder platform on coeliac disease (CDEUSSA)," Aliment Pharmacol Ther, 27(11), 1030-1043, Jun 2008.

[52] Anca, I., Stănescu-Popp, A., Arama, V., Duță, D., Alexe, G., Colcer, F., "Celiac disease: diagnostic criteria and impact of gluten free diet--patients' perspective,” Rev Med Chir Soc Med Nat Iasi, 112(2), 351-355, Apr-Jun 2008.

[53] Samaşca, G., Iancu, M., Pop, T., Butnariu, A., Andreica, M., Cristea, V., Dejica, D., „Importance of the Educational Environment in the Evolution of Celiac Disease," LabMedicine, 42(8), 497-501, Aug 2011.

[54] Parco, S., Città, A., Vascotto, F., Tamaro, G., "Celiac disease and immigration in Northeastern Italy: the "drawn double nostalgia" of “cozonac" and "panettone” slices,” Clin Exp Gastroenterol, 4, 121-125, May 2011.

[55] Ozkan, M., Trandafir, L., Mîndru, E., Moraru, E., "Variability of nutritional status and of the parameters of lipid metabolism in gluten-free diet," Rev Med Chir Soc Med Nat Iasi, 116(1), 103107, Jan-Mar 2012.

[56] Ribeiro, M., Poeta, P., Igrejas, G., "The Genetic Variability of Wheat Can Ensure Safe Products for Celiac Disease Patients?" International Journal of Celiac Disease, 2(1), 24-26, 2014.

[57] Lupan, I., Sur, G., Deleanu, D., Cristea, V., Samasca, G., Makovicky, P., "Celiac disease microbiota and its applications," Annals of Microbiology, in press, Dec 2013.

[58] Litwinek, D., Ziobro, R., Gambuś, H., Sikora, M., "Gluten Free Bread in a Diet of Celiacs," International Journal of Celiac Disease, 2(1), 11-16, 2014.

[59] Oancea, S., Stoia, M., “Gluten screening from pharmaceutical products, an imperative for celiac disease management," Farmacia 57(1), 99-103, Jan-Feb 2009.

[60] Oancea, S., Wagner, A., Cîrstea, E., Sima, M., “Gluten screening of several dietary supplements by immunochromatographic assay,” Roum Arch Microbiol Immunol, 70(4), 174-177, Oct-Dec 2011. 